体力科学 (2007) $56,18 \sim 19$

【教育講演 4 : 脳が作る感覚世界一生体にセンサーはない】

脳が作る感覚世界一生体にセンサーはない

\author{
小林茂夫 \\ (京都大学大学院情報学研究科知能情報学専攻)
}

要約

これまで, 感覚器の受容器は物理量のセンサーで あり，物理量の情報をインパルスの発火頻度という 符号に変えて脳に送り，脳が光の符号を解読すると いわれてきた .これに対し, 受容器は, 外の物理量 を分割してとらえる帯域比較器だと私は唱える.帯 域にはいる物理量が届くと受容器のスイッチがつ き，インパルスを引き金として出す．インパルスが 脳に届いて自己ニューロンが興奮すると,備わる「情 報」が発現して人に感覚が生まれる.かくして, 受 容器がセンサーから比較器に変わると, 感覚の説明 原理が一変する .ニューロン間を伝わるインパルス が情報を伝えるとの見方谷のものが棄却される .こ こでは, 感覚の新しい説明原理を述べる1).

1. 背 景

私たちは，ふつう，暑さ・寒さ，においや味，音 や色が体の外にあり，光れらを感覚でとらえると思 っている．これは，感覚を生む情報は外にあり，脳 にはないと説く哲学の経験論の見方である ${ }^{2,3)}$.

しかし, 暑さ・寒さやにおい, 味, 音, 色は私た ちの心に生まれる感覚であって，体の外にはない． 現実に外にあるのは, 温度やもの, 空気波や電磁波

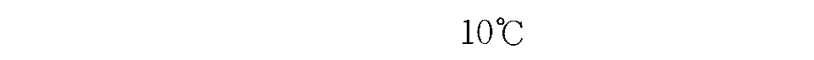
屋が寒いと私たちが感じることは, まったく別の現 象である、物理量の情報が脳にはいり感覚に変わる とする経験論では, 人の感覚は説明できない．

哲学の生得説は, 感覚を生む「情報」は生まれつ き脳にあるとする ${ }^{4)}$. 温度が $10^{\circ} \mathrm{C}$ のき, 受容器が 活動し脳を刺激する．すると，脳に備わる「情報」 が発現し, 皮膚が冷たいとの感覚が生まれるという. 生得説は, 物理量と感覚の違いを認めたうえで, 両 者を関係づける．これなら原理的に感覚が説明でき る.

2. 受容器はセンサーか?

これまでの生理学の感覚の説明は, エイドリアン
の本 ${ }^{5)}$ に依存する . 彼は, 刺激に応じて受容器が出 すインパルスを記録した。炎して，受容器は物理量 をインパルスの符号に変えて脳に送り，脳では符号 が解読されて感覚に変換されるという.これは経験 論に沿う説明だ .

だが，乥れでは感覚か説明できないと，彼は本の 最後に認める. 刺激を受けると , どの受容器もイン パルスを出す . だから , インパルスは物理量のちが いを示す符号ではない．むしろ，インパルスが脳に 向かって通る路が感覚を決めるという.これは, 感 覚を生む「情報」は脳にあるとする生得説の見方で ある

このように, エイドリアンの説は, 経験論か生得 説かが明らかでなく，物理量と感覚が混同されてい る.しかし, 生理学的な実験か評価され, 彼はノー ベル賞を受ける(1932年)。

その後の生理学は, 生得説の側をしり光け,「受 容器はセンサーだ」との経験論一色になる，光こで 感覚が説明できない状況が今も続く.

3. 受容器は比較器だ

皮膚には, 閾より高い温度域で活動する高温受容 器と, 閾より低い温度域で活動する低温受容器があ る. 温度受容器の遺伝子が, 最近, 次々と見つかつ た .これらは, Transient receptor potential(TRP) チャネルのメンバーであり， ミントやトウガラシな どの刺激物にも応答する。

ここでは, 人工のセンサーと比較器を参照し, 温 度受容器がセンサーでなく比較器だと述べる．

人工のセンサーは, 温度を符号に直して受信部に 送る. 受信部では符号が解読されて温度が表示され る. 乥こで, センサーの出力は温度の変化に忠実に 従う必要がある . また, 温度以外のものに反応すべ きでない.しかし, 高温受容器や低温受容器が引き 起こすインパルス活動は, 温度変化に対して閾応答 や過渡応答, 山型応答を示し, 温度の変化に追従し ない. しかもミントなどにも応答する.だから温度 
受容器は, 温度のセンサーではない

人工の比較器は, 温度が基準より高い時や低い時 にだけ，標的を駆動する信号を出す．高温受容器， 低温受容器は, この条件にあてはまるので, 比較器 といえる1). また, 温度受容器は, ミントやトウガ ラシが加わると活動する.だから, 温度受容器は, 化学物質の濃度が閾より高いときに活動する帯域比 較器でもある.

温度受容器だけでなく，すべての受容器は，外の 物理量を分割してとらえる比較器とみなせる．すな わち生体にセンサーはない .この見方に立つと，感 覚系の説明原理が一変する。

\section{4. 反射調節}

これまで, 温度受容器からの温度情報を受けて皮 膚温を調節するサーモスタットが脳にあるといわれ てきた . だが, 受容器の出すインパルスは温度の符 号ではない，皮膚温が伝わらないのだから，皮膚温 を調節するサーモスタットは脳にはない . 低温受容 器からヒーターまで, 高温受容器からクーラーまで 配線があれば, これらの受容器弚のものがサーモス タットとして働き, 皮膚温の過度の上昇, 低下を防 ぐ.

筋紡錘にある伸張受容器は，筋の長さが閾を超す と活動する比較器である. 兴の出力が運動ニューロ ンを介して同じ筋につながる時, 受容器は伸張反射 の中枢として働き，筋長の過度の伸張を防ぐ．

5. 感 覚

活動域にはいる物理量が届くと, 受容器は脳の標 的の細胞に向けてインパルスを出す(图 1 ). 炎のと き, 物理量についての感覚が生まれる．たとえば皮

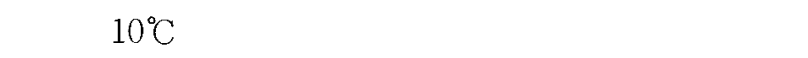
る.だから標的の細胞には, 自己に感覚を生む「情 報」があるにちがいない，光こで標的の細胞を自己 ニューロンと呼ぶことにする．弚れ以外のニューロ ンを, 普通ニューロンと呼ぶことにする(受容器を 持つ細胞は普通ニューロンである）.

すると，感覚か説明可能になる．皮膚温が $10^{\circ} \mathrm{C} の$ 時, 受容器が働いてインパルスを出す. 兴のインパ ルスで自己ニューロンが活動すると，備わる「情報」 が発現し，皮膚が冷たいとの感覚が自分の心に生ま れる．つまり感覚系は比較器と自己ニューロンから 成り，物理量と感覚を関係づける。これは，生得説 の生理学的な説明といえる.

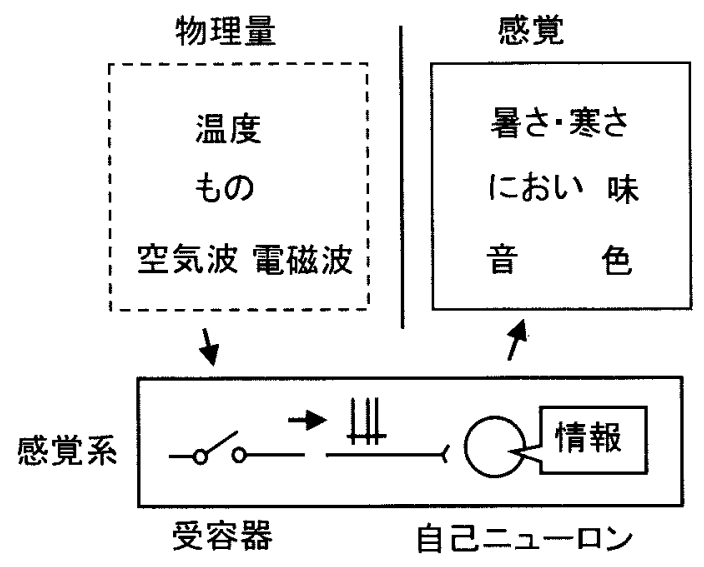

図 1 . 感覚系の新しいパラダイム 感覚系は物理量と感覚を関係づけるしくみであり，受容 器と自己二ューロンからなる.受容器は, 物理量を分割 してとらえるもので, 帯域比較器として働く.帯域には いる物理量が届くと, 受容器が活動してスイッチがつき インパルスを出す．インパルスで脳の自己ニューロンが 興奮すると「情報」が発現し, 物理量についての感覚が 人の心に生まれる .

\section{6. 自己ニューロンが心を生む}

これまで, 脳のニューロン間を行き来するインパ ルスで情報が伝わり，神経回路で処理されるといわ れてきた .これは脳が人工の論理回路に似るとする 見方だ . だが，インパルスは符号ではない . 標的二 ューロンの引き金である .このことは，心を生む「情 報」が自己ニューロンの中にだけあり，出入りする ものではないことを示す．インパルスで自己ニュー ロンが興奮すると，「情報」どおりの感覚や記憶， 運動などが人に生まれるといえよう.いいかえると， もし「情報」が自己ニューロンにないなら，人に心 は生まれない .

$$
\text { 結語 }
$$

受容器を比較器ととらえると, 感覚系の枠組みが 一変し, これまでの生理学とは違う視界が開ける。

\section{参 考 文 献}

1) 小林茂夫，脳が作る感覚世界一生体にセンサ一はな い.2006: コロナ社 .

2) アリストテレス 心とは何か：講談社(桑子敏雄二訳， 1999) .

3) ジョン・ロック，人間知性論 .1690 : 岩波書店 (大槻 春彦二訳, 1972) .

4) デカル卜, 情念論 . 1649：中央公論新社(野田又夫= 訳, 2002).

5) Adrian, E. D., The basis of sensation. 1928, London : Christophers. 